\title{
Voxel 表現に基づく多軸制御加エ切削シミュレーションの 大規模並列処理手法*
}

\author{
- グラフィックハードウェアのアーキテクチャを考慮した状態記述/干渉判定法 - \\ 土 棚 善 貴** 金子順 一*** 堀 尾 健 一 郎***
}

Fast Simulation Algorithm of Voxel Representation Method for Multi Axis Control Machining

- Geometric Representation and Collision Detection Considering the Architecture of Graphic Hardware -

Yoshitaka TSUCHITANA, Jun'ichi KANEKO and Kenichiro HORIO

This study proposes a new simulation method of workpiece shape with voxel representation for multi axis controlled machining process. Usually, voxel representation requires enormous number of computational complexity and computer memory to estimate accurate shape of machined workpiece. In this paper, a new simulation algorithm based on octree collision detection with multi level voxel representation is proposed. The proposed algorithm is designed to adapt an characteristic of GPU hardware architecture for parallel processing. In the proposed algorithm, as attribute of each voxel, block number of NC program from the moment when the voxel is machined with endmill is described in computer memory. Then, by referring the attributes, the voxeles locate near the cutting tool can be identified within a short time. By applying the proposed algorithm, the prototype simulation system is developed. The developed system can estimate shape of the workpiece in machining process within a several micro seconds at an arbitrary moments.

Key words: NC machining, multi axis controlled machining, cutting simulation, voxel representation, GPGPU

\section{1. 緒言}

近年，多軸制御 NC 工作機械を使用したエンドミル加工では 素材から完成形状までの加工を同一加工機上で把持条件を変え ることなく実施する一貫加工が広く実施されつつある。この種 の加工では, 被削物とツール, 機械構造物との衝突が頻発する 反面, 加工の進展に伴い被削物形状が大幅に変化する. そのた め工具経路の生成時に加工途中の各段階における被削物形状を 推定し参照することが重要な課題となる. これに対し，一般的 な CAM ソフトウェアパッケージにおいては, 工具経路決定に際 して被削物の形状変化を評価する切削シミュレーションが備え られ，工具刃先による被削物の削りすぎや削り残し，被削物々 ツール，機械構造物との衝突の検出が実施されている.

加工途中の被削物形状の記述手法としては, 従来より CAD シ ステムのソリッドカーネルの利用や, 空間を離散的に分割して それぞれの領域における形状の存在を表現する手法が提案され ている. 後者の代表的なものとしては, 2 次元基準平面上に格子 点を等間隔に設定し，これを通過する並行な直線と被削物表面 との交差位置を記述する Z-map ${ }^{1) 33}$ 法や，図 1 に示すように空間 を一定間隔で分割し，各領域に物体が存在するかの属性を記述 する Voxel 表現法 ${ }^{4)}$ 等が挙げられる.このうちVoxel 表現法では, 工具の運動に伴い切れ刃によって除去されたと考えられる領域 を工具形状と各 Voxel との内外判定によって特定し, 該当箇所 の属性を変更することにより切削加工による被削物の形状変化 を表現することが可能である，本表現法は，工具の姿勢変化や 加工対象物のオーバーハング, 立壁等の複雑な形状に対応しや すいため, 多軸制御切削加工に対応した被削物形状評価では多

\footnotetext{
* 原稿受付 平成 24 年 9 月 19 日

** 学生会員 埼玉大学大学院(埼玉県さいたま市桜区下大久保 255)

*** 正会員 埼玉大学大学院
}

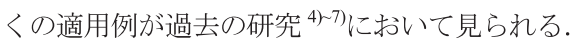

Voxel 表現を用いた切削シミュレーションでは, 形状表現を高 精度化するにあたって記述に必要となる計算機メモリの総量と, 多数の Voxel と工具との間での干渉判定の高速化がそれぞれ大 きな課題となる. これらの問題に対し, 過去の研究では, Octree 形式の記述手法の導入による状態記述の効率化手法が提案され ている ${ }^{8)}$. Octree 形式によるVoxel 記述では, 図 2 のように $1 つ$ の Voxelによって表される領域をさらに一辺が $1 / 2$ となる Voxel の集合として表現し, 再帰的に形状を表現することによって Voxel の総数を抑制しながら微小な被削物表面形状の記述が可 能となっている.

一方, 干渉判定の高速化では, 近年 GPU を用いた大規模並列 計算が CAM においても提案されつつある ${ }^{9)}$. GPU(Graphics processing unit)は 3 次元 CG の描画用ハードウェアから発達した 超並列計算機器であり, 数百程度の処理ユニットを同時に実行 させ, 高い並列処理計算を実施することが可能となっている. 近年では, GPU の能力を科学技術計算等の処理を行うためのラ イブラリが実用可能となっており, 汎用的な目的に GPU を利用 する GPGPU(General-purpose computing on graphics processing units)が一般的な大規模並列計算機技術となりつつある. 本研究 では, 過去に提案された Octree 形式での高精度 Voxel 表現手法 を GPU の並列計算機能を効率よく利用可能な方式に拡張し, 切 削シミュレーションを高効率に実施するための処理アルゴリズ ムを提案する. 具体的には, Voxel 表現法における Voxel の属性 記述を切削加工向けに拡張し, GPU-CPU 間の情報転送のオーバ 一ヘッドを局限するためのメモリ設定法の開発を行った.

\section{GPU を用いた大規模並列計算に対応した 被削物の Voxel 形状表現}

Octree 形式の Voxel 表現法を用いて GPU 上で切削シミュレ 
ーションを行う際の課題として, GPU 上で処理を行う際の同時 に処理を行うプロセス数の確保と CPU-GPU 間でのデータコピ 一に伴うオーバーヘッドの問題が挙げられる. 図 3 に示すよう に, GPU 上での大規模な並列計算は CPU 上で処理を行う対象 となるデータとプログラムを用意し,これを GPU 上に転送して 処理を行い, 結果を CPUに再び転送する過程の繰り返しによっ て実現される.このとき，GPU の処理は 1.プログラムおよび処 理に必要となるデータの CPU からの転送, 2.工具と各 Voxel との干渉検出および Voxel 属性変更の並列処理による実行, 3. 処理結果のデータの CPU への転送, からなり, 処理の並列化が 小規模な場合にはしばしば処理時間の大半を 1. および 3. が占め る. 従来の Octree 形式の Voxel 表現の元で切削シミュレーショ ンを行う際には, Voxel がより小さい Voxel の集合に分割され た時点で再帰的に干渉判定が行う必要が生じる。一般的な 2 分 木による Octree 形式の表現手法では， 1 つの Voxel が $2^{3}=8$ 個 の小 Voxel の集合とみなされ, これらが並列処理の最小単位と なる. 一方, 近年の GPUを用いた並列計算において, GPUが 同時並行に動作させることの可能な計算コアの総数は数百以上 であり, 同時に干渉の判定を実施することの可能な Voxel の総 数を計算コアと同数か整数倍になるよう設定するアルゴリズム が GPU を用いた効率的な形状表現の実現に必須になると考え られる.

そこで, 本研究では GPU による並列処理における干渉判定の 効率を高め, 計算時間を短縮するため, 切削シミュレーション を対象とした Voxel 記述属性の拡張と, Voxel 間の相対的な位 置関係を考慮したメモリ空間の設定法の提案を行う．以下では それらの詳細について述べる。

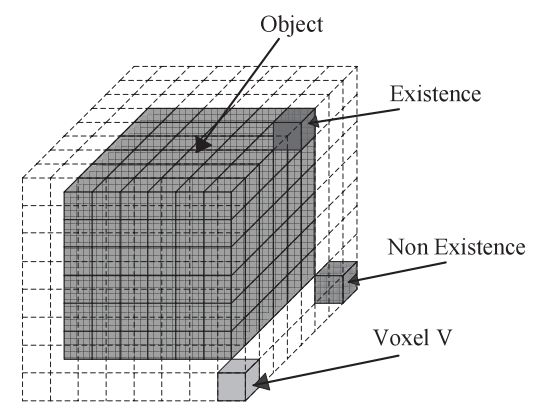

Fig.1 Voxel representation method

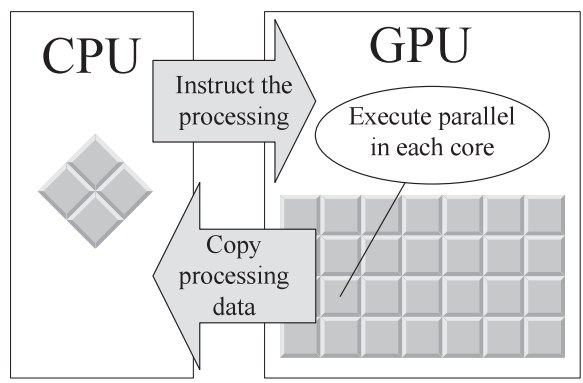

Fig.2 Concept of octree method

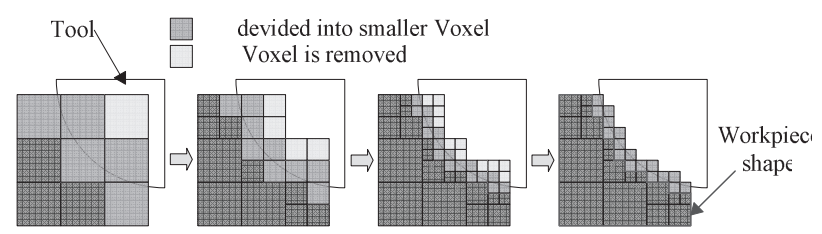

Fig.3 Parallel computing using GPU

\section{1 大規模並列処理に対応したVoxel 状態記述の拡張}

本研究では, 数百個以上の計算コアに同時に工具と Voxel と の干涉判定を実施させ，かつ GPU-CPU 間のメモリ転送量を減 少させるため, 以下の 2 点の形状記述法を導入する. まず, 図 4 に示寸ように Octree 形式での Voxel 内部の空間分割を, 一般的 な 8 分割から, 3 方向に対して等しい長さに $\mathrm{n}^{3}$ 分割する手法を 導入する. 過去の研究では, 8 分木による再帰表現を $\mathrm{m}$ 回繰り 返すことにより，1/2m の大きさのVoxel を最小の単位として形 状の記述を行う手法が提案されている. これに対し, 本研究で は再帰的な形状記述を 1 回のみ行うとし, 上位の Voxel 表現に おいて工具刃先が通過すると考えられる領域の夕を $1 / n$ の大き さのVoxel の集合として形状の表現を行う．以降では，加工対 象物のある空間に対して初期に設定される Voxel の集合を Level1 Voxel, Level1 Voxelに比して1/nの大きさの Voxel の 集合を Level2 Voxel とする.

前節で述べたように, GPU は数百個以上の計算コアを同時並 行に動作させることが可能である一方, 並列計算の準備および 結果の CPU 上一の転送に大きな処理時間が必要とされる.一般 的な Octree 形式の Voxel シミュレーションのように, Level1 の個々の Voxel に対して工具との干渉判定を GPU 上で逐次実 施し, 干渉の生じた Voxel に対して新たに Level2 の Voxel を設 定して干渉判定を行うことは GPU 上でのメモリ領域の確保お よびGPU-CPU 間でのデータ転送に必要とされる時間から効率 的ではない，そこで本研究では, Level1のVoxelにおける形状 表現を通常の物体の有無から，工具刃先通過の有を示寸 3 状態 に拡張し, これを元に Level2 に対応する Voxel についての干渉 判定が必要となるかどうかを判断する手法を提案する.

図 5 は Level1 における 3 つの Voxel 属性の概要を示す, 加工 対象物の該当する領域が全て存在する"Full"属性と, 全て取り除 かれた"Removed"属性に対して, Voxel の領域の一部が工具切 れ刃の通過によって取り除かれた状態を"Chipped"属性として 定義する．干渉判定では，工具が新しい位置に移動するごとに 工具中心軸に対する各 Voxel の距離 $\mathrm{r}$ および工具刃先先端から の距離 $\mathrm{L}$ を導出し, これと工具切れ刃の各部での半径 $\mathrm{r}(\mathrm{L})$ と の大小を比較することにより属性を更新する.

提案手法での干涉判定の手順を図 6 に示す. まず加工対象物 が存在すると考えられる領域を包含する Level1 のVoxelに対し， 工具との位置関係から"Full", "Removed", "Chipped"の各属性 の判定を行う.これらの判定は Level1 の全ての Voxel を同時に 対象とする並列処理によって実施することが可能である. 次に, Level1 Voxel のうち, "Chipped"の属性を持つ Level1 Voxel が存在する領域に対応する Level2 Voxel の集合に対して工具と の干涉判定を行う。この際, 対象の Level1 Voxel に対応する領 域は $\mathrm{n}^{3}$ 個の Level2 Voxel からなるため, これらを並列処理の対 象とすることで GPU を用いた高効率な干渉判定が実現できる.

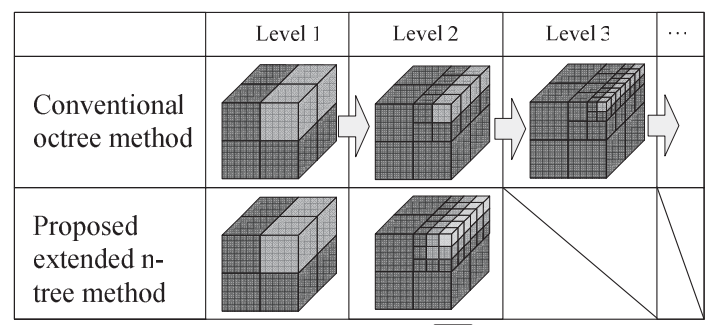

Full $\square$ Chipped $\square$ Removed

Fig. 4 Extended octree method 

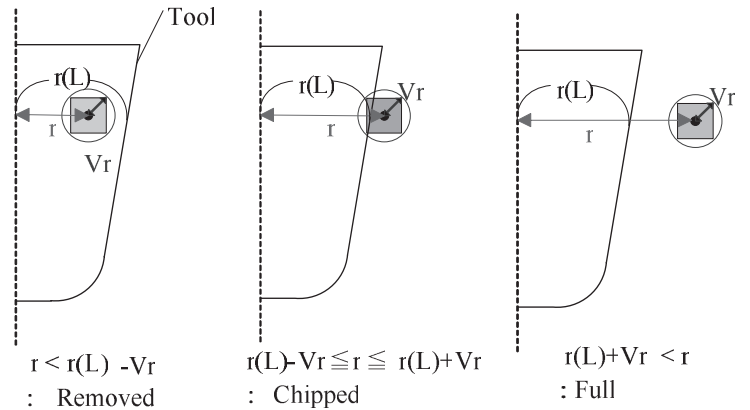

Fig.5 Attribute of voxel

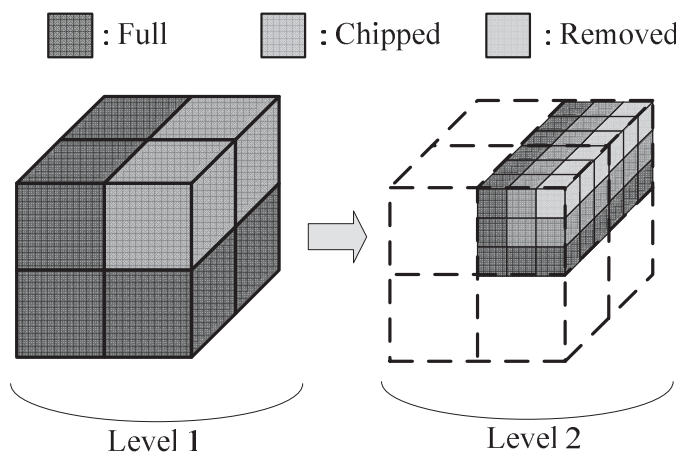

Fig.6 Procedure of interference judgement

\section{2 工具通過履歴情報を用いた Voxel 状態の時空間記述}

前節においては, 一般的な 8 分木を用いた Octree 形式での再 帰的 Voxel 形状記述に対して, GPUによる並列処理に適応した $\mathrm{n}^{3}$ 分木による記述手法について述べた，本節では，更に $\mathrm{NC}$ 加 工において得られる工具運動の順序情報を用いた干渉判定処理 の効率化について述べる.

図 7 に示すように, "Chipped"の属性を持つLevel1 Voxel の 領域を干渉判定の対象とする手法では, 過去に"Chipped"となり, 現在は工具が近傍にない空間についても干渉判定を実施する必 要が生じる. また, Level2 の Voxel が全でRemoved"となった 領域については加工対象物が存在しないと考えられるため, こ れに対応する Level1 Voxel の属性を"Removed"に変更しない場 合, 必要のない干渉判定が繰り返される場合がある。これらの 問題を解決するため, 本研究では前節で述べた"Chipped"の属性 表現をさらに拡張し, 工具運動の履歴情報を Level1 Voxel に与 えることで Level 2 Voxel を対象とした干渉判定の効率を向上 させる.

提案手法の概念を図 8 に示寸. 工具の通過に伴い, Level1 Voxel の属性が"Chipped"となる場合には, その瞬間の工具の運 動ステップの番号をLevel 1 Voxel の属性として設定する。 こ れにより, Level2 Voxel の工具との干渉判定の際に, 現在の工 具位置に対応する運動ステップ番号と, Level 1 Voxel の属性が 有する番号を比較し，一致する部分のみを干涉判定の対象とす る. 切削工具による形状の変化は, 工具切れ刃が通過する可能 性のあるVoxel においてのみ生じると考えられる，形状変化が 起こる可能性のある Level 2 Voxel を Level 1 Voxel の干渉判定 時に工具運動ステップ番号を参照して特定することにより, Level2 Voxel に対する干涉判定処理そのものおよび, GPU-CPU 間のメモリ転送回数の大幅な省略が可能となる.

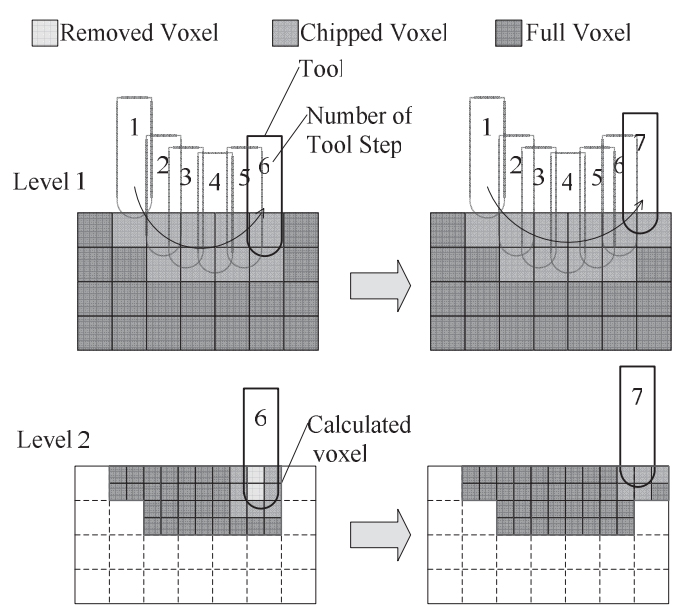

Fig.7 Interference judgement using conventional method
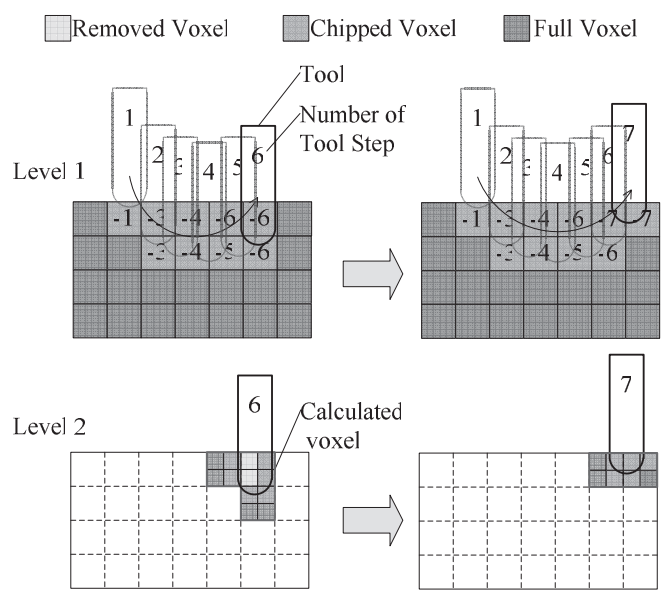

Fig.8 Interference judgement using proposed method

\section{3 並列処理を考慮したVoxel 記述メモリの設定法}

前節においては, Level 1 および Level 2 のつの大きさの Voxel 表現と，工具運動の履歴情報を用いた Voxel の属性值設 定について述べた。 この提案手法では, Level1 Voxelのうち, "Chipped"の属性を持つ Level1 Voxel が存在する領域に対応す る Level2 Voxel の集合に対して工具との干涉判定が行われる. 干渉によるVoxel の状態の遷移を記述メモリに反映させる際に は対象となるVoxel の現在の状態を参照し，これが変化するか どうかの判定を行う必要がある. 一般的に, Voxel の状態を記述 する際には, 縦横高さの 3 方向に対して $(\mathrm{i}, \mathrm{j}, \mathrm{k})$ 個の要素を持つ Voxel の集合に対して, 以下のような一次元配列 $V\left[i^{*} j^{*} k\right]$ を用い た記述が行われる.

このようなメモリ設定を本研究で提案する Level2 までの Voxel 記述法に適用した場合, Level 1 の Voxel のうち, 繸 $\mathrm{p}$ 番 目, 横 $\mathrm{q}$ 番目, 高さ $\mathrm{r}$ 番目の $\operatorname{Voxel}(\mathrm{p}, \mathrm{q}, \mathrm{r})$ に対応する Level 2 の 各 Voxel の状態は, 図 9 に示すように一次元配列上において飛 び飛びに存在する $\mathrm{n}$ 個の連続した領域によって記述されること となる.

一般に GPU を用いた並列処理では, 処理に際してこのように 不連続に配置されたメモリ領域を参照して計算を行う場合, 処 理の準備段階において低速な CPU 上のメモリ，もしくは GPU 上の共有メモリにアクセスし, 図 10 のように連続したメモリ領 域に一旦コピーを行った後, GPU コアに情報を転送する必要が 


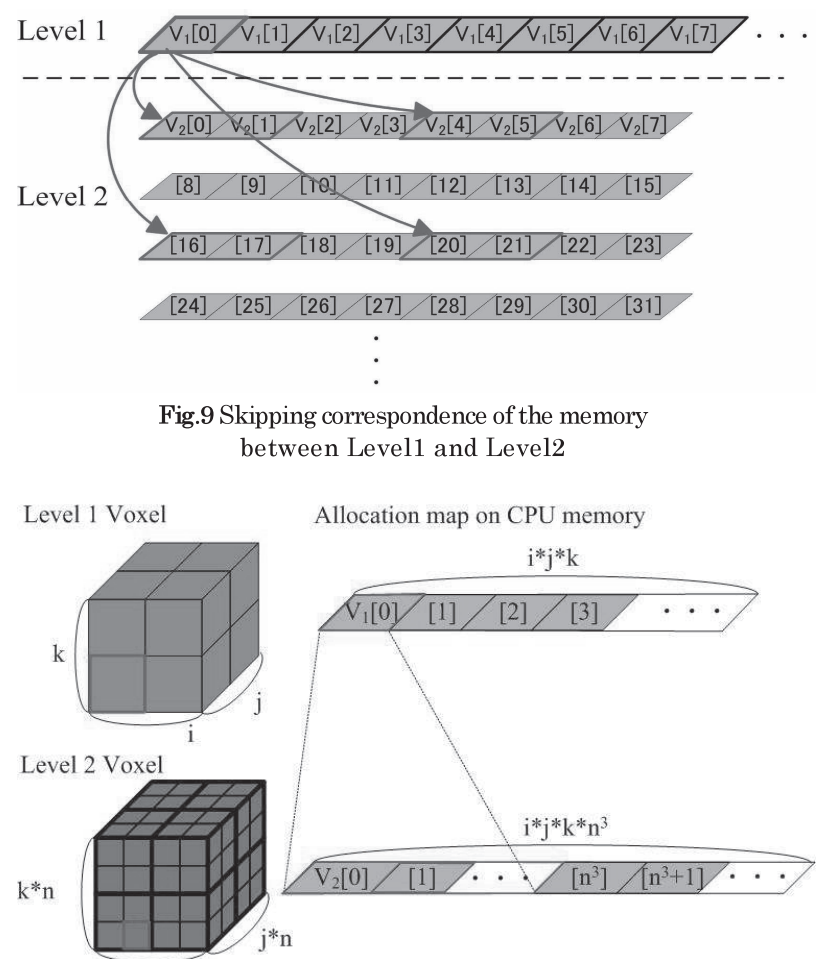

Fig.10 Consecutive correspondence of the memory between Level1 and Level2

生じる. このことは, Level2 の各 Voxelに対する干渉判定を実 施するたびに Level2 のほぼ全てのVoxel の属性を記述するメモ リ領域に対するアクセスを繰り返す必要があることを意味し, 干渉判定速度の大幅な低下が発生することが想定される.

そこで本研究では, Level2 のVoxel における属性記述の順序 を変更し, Level1 のあるVoxel が干渉を生じた場合に, それに 対応する Level2 のVoxelの属性を連続したメモリ領域のコピー によって GPU に転送できる新しい記述順序を導入する. 図 10 はその概要を示す. Level 1 の Voxel のうち, 横 $\mathrm{p}$ 番目, 縦 $\mathrm{q}$ 番目, 高さ $\mathrm{r}$ 番目の $\operatorname{Voxel}(\mathrm{p}, \mathrm{q}, \mathrm{r})$ の領域に存在する $\mathrm{n}^{3}$ 個の Level 2 Voxel の状態は, それぞれ以下のような順序で一次元配列状に格 納されて記述される.

$$
\mathrm{N}=\mathrm{r}^{*} \mathrm{j} * \mathrm{i}+\mathrm{q}^{*} \mathrm{i}+\mathrm{p}
$$

式(1)の順序で Level2 の Voxel の状態を記述することにより， Level1 Voxel が Chipped の属性を持つ場合, 対応寸る領域にお ける Level2 Voxel の評価では, V[N*n $\left.\mathrm{n}^{3}\right]$ から始まる連続した $\mathrm{n}^{3}$ 個のメモリ領域を一括して転送することにより，GPU コアでの 並列計算が可能となる.

\section{3. 開発手法の処理アルゴリズム}

本提案手法の有效性を検証するため, 商用 CAM ソフトウェア で出力された同時 5 軸制御加工の CL データを読み込み, 荒加工 と仕上げ加工における加工対象物の形状変化を評価する検証用 の試作切削シミュレーションシステムを開発した. 図 11 は開発 したシミュレーションシステムのアルゴリズムを示す.

本システムでは, Level1 Voxel および Level2 Voxel の属性を記 述する一次元配列を CPU 側と GPU 側のそれぞれに $\mathrm{V} 1, \mathrm{dV} 1, \mathrm{~V} 2, \mathrm{dV} 2$ として確保している. 処理の過程では, まず Levell の Voxel のうち, Full と Chipped となっている Voxel に対

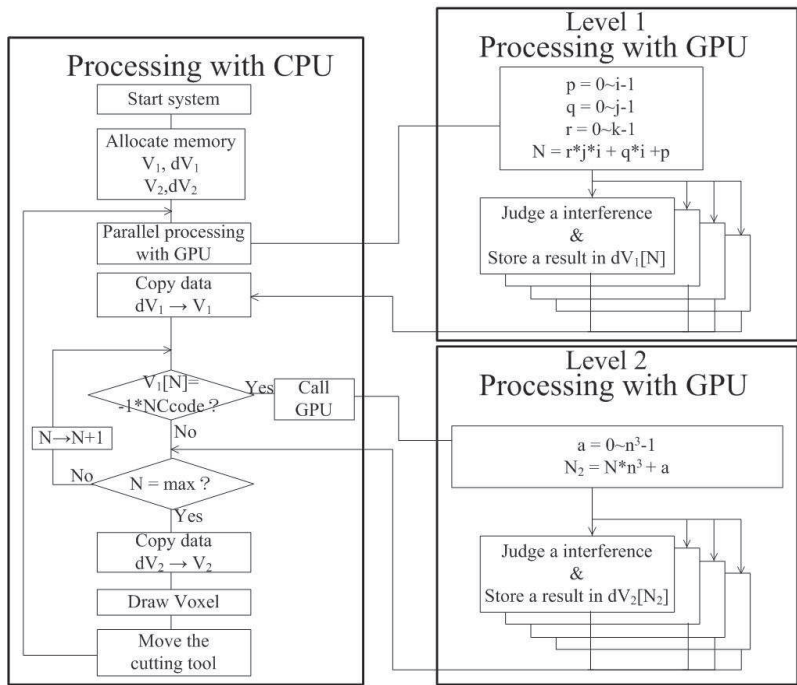

Fig.11 Algorithm of proposed method

する干渉判定を GPU 上で実施し結果を $\mathrm{dV} 1$ に反映させる. そし てこれを CPU 側のV1にコピーして CPU 上での形状変化の判定 を可能とする.

次の過程では, CPU 側の V1 について, 各 Voxel の属性值を 順次判定し, 現在切削工具が存在している工具運動ステップの ID を有する Chipped の Voxel のみに対して, 該当する領域の Level2 Voxel における干渉判定を実施する。この際は 2.3 節で述 べたように GPU 上の $\mathrm{dV} 2$ 配列の中途から $\mathrm{n} 3$ 個の連続した領域 を対象とした干涉判定を実施し, 結果を $\mathrm{dV} 2$ 配列から V2 へと コピーして反映する.

最後に工具運動による形状変化を描画結果に反映するため, $\mathrm{CPU}$ 上の V2 領域を参照し, Voxel 形状のなかで外部に露出する 表面形状を画面に描画する。これらの処理を NC プログラム上 の工具運動に従って微小距離ずつ連続して行い, 画面上での加 工対象物の形状変化を可視化する.

\section{4. 並列処理による処理高速化の計算機実験による検証}

\section{1 可視化実験条件}

試作システムの実装にあたっては，現在， $\mathrm{CAD} / \mathrm{CAM} / \mathrm{CAE} ソ$ フトウェアにおいて広く用いられている OpenGL グラフィック ライブラリと, GPGPU 用計算ライブラリである NVIDIA 社の CUDA ライブラリを使用した。 また，使用した PC に搭載され ている CPU・GPU は表 1 に示した通りである. 被削物の初期形 状は 1 辺 $135 \mathrm{~mm}$ の直方体とし, CL データとして, 商用 CAM ソフトウェアである Hypermill を使用し, 図 12(a)の素材形状か ら, 直径 $20 \mathrm{~mm}$ のスクエアエンドミルによる荒加工後, 直径 $6 \mathrm{~mm}$ のボールエンドミルによる仕上げ加工を行い, 図 12(b)の形状を 創成する総工具運動ステップ数 30000 の工具経路を生成して評 価を行った.

開発したシステムにおいては, 被削物の初期形状は横方向に i 個, 縦方向に j 個, 高さ方向に $\mathrm{k}$ 個の Level1Voxel で表現され, さらに Level1 Voxel1 個には $\mathrm{n}^{3}$ 個の Level2Voxel が配置され表現 される. 今回の評価では被削物の初期形状は立方体としている ため, $\mathrm{i}=\mathrm{j}=\mathrm{k}$ として評価を行う.よって, 被削物の 1 辺は $\mathrm{i}$ 估 の Level2Voxelにより表現されることとなり,$i^{*} n=D$ と置いて 評価している. 
Table1 Performance of PC

\begin{tabular}{c|c|c}
\hline & CPU & GPU \\
\hline Name & Intel Xeon & $\begin{array}{c}\text { Tesla } \\
\text { C2050 }\end{array}$ \\
\hline Clock & $3.33 \mathrm{GHz}$ & $1.50 \mathrm{GHz}$ \\
\hline Memory & $12 \mathrm{~GB}$ & $3 \mathrm{~GB}$ \\
\hline CUDA core & & 448 \\
\hline
\end{tabular}
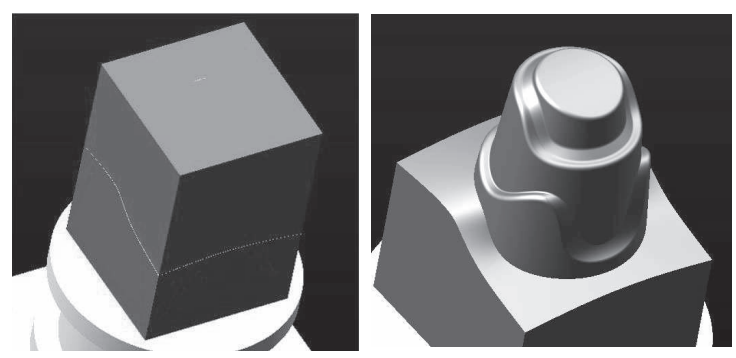

(a) Stock shape

(b) Finished shape

Fig.12 Workpiece shape for experiment

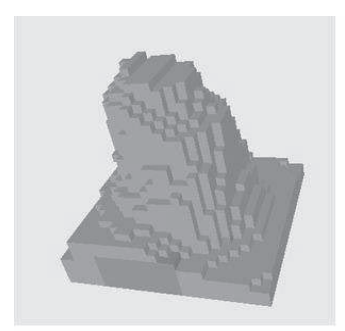

(a) $\mathrm{D}=25$

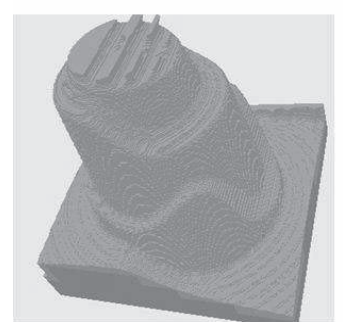

(c) $\mathrm{D}=225$

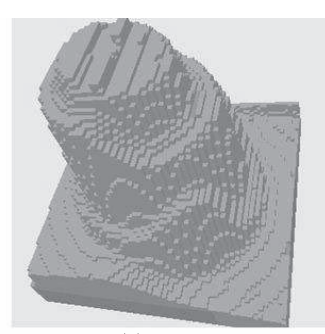

(b) $\mathrm{D}=64$

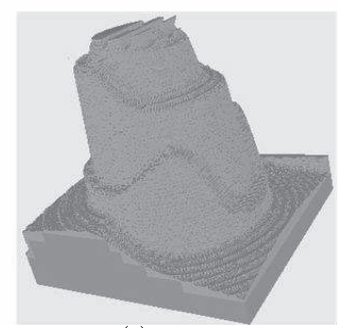

(d) $\mathrm{D}=400$
Fig.13 Approximated shape of machined workpiece rendered by the developed system

\section{2 試作システムの評価}

本評価では $\mathrm{i}=\mathrm{n}$ とし, 被削物 1 辺あたりの Level2Voxel 数 D を変化させて評価を行った. 図 13 は各 D における加工終了後の 被削物形状の可視化結果である. D が増えるに従って, 表現精 度が向上していくのがわかる.

また手法の有用性を評価するため，D を変化させた場合の処 理時間をそれぞれ比較した。その結果を図 14 に示す。

系列 A は 2-1 で述べた Voxel 状態記述を拡張した干涉判定法を 導入したもの, 系列 B は 2-2 で述べた工具運動のステップ番号 をVoxel の属性として記述する手法を導入したもの, 系列 C は さらに 2-3 で述べたメモリの設定手法を導入したものである. 2-2 の手法の適用により, 処理時間は約 5 分の 2 に短縮されてい る. また, 2-3 の手法を導入した結果, A に比べて約 67 分の 1 にまで処理時間が短縮されている.

4. 3 Level1, Level2 の Voxel 数の配分による処理時間の評価 4.2 においては $\mathrm{i}=\mathrm{n}$ として評価を行ったが, 被削物 1 辺あたり の Level2Voxel 数 D が同じ場合でも, $\mathrm{i}$ と $\mathrm{n}$ の配分の違いによっ

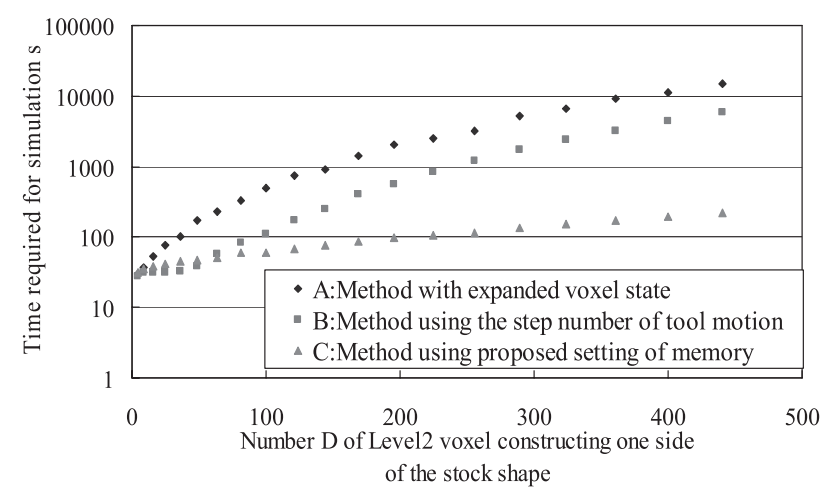

Fig.14 Time required for simulation using each proposed method

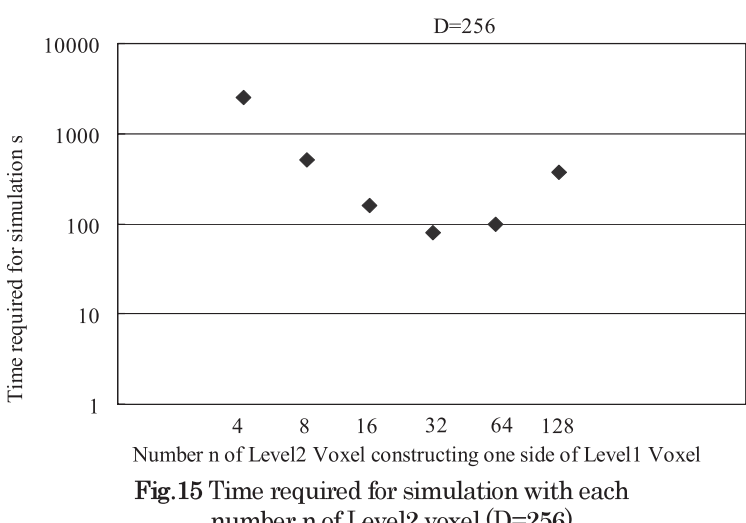
number $n$ of $\mathrm{Level} 2$ voxel $(\mathrm{D}=256)$

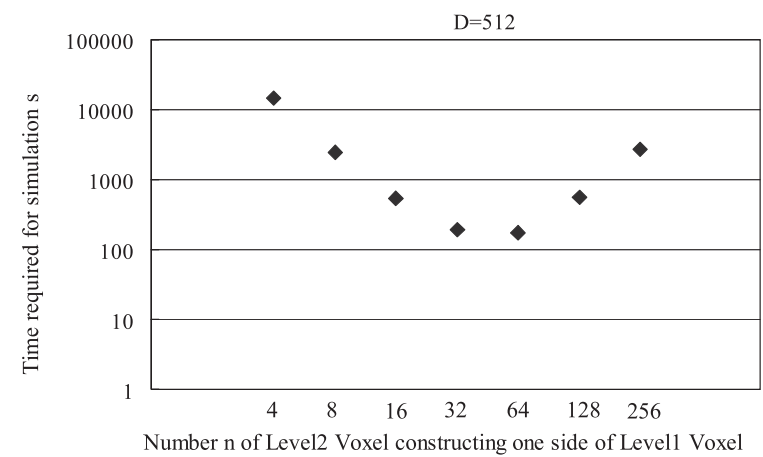

Fig.16 Time required for simulation with each number $\mathrm{n}$ of Level2 voxel $(\mathrm{D}=512)$

て処理時間に差が生じると考えられる。そこで，本評価では $\mathrm{D}=256$ と $\mathrm{D}=512$ の場合において, i と $\mathrm{n}$ の配分を変化させてシ ミュレーションの所要時間をそれぞれ測定した，その結果を図 15, 図 16 に示す，縦軸はシミュレーション所要時間，横軸は Level1Voxel1 辺あたりの Level2Voxel 数 nを示している.

$\mathrm{D}$ を同一とした場合, Level1 の分割数 $\mathrm{i}$ は $\mathrm{i}=\mathrm{D} / \mathrm{n}$ によって決 定されるため, $\mathrm{n}$ と $\mathrm{i}$ は反比例の関係になっている. $\mathrm{n}$ が大きい 場合，GPU 上で同時に処理されるプロセス数が多くなり，並列 処理の効果が拡大寸るため処理時間が減少する。 また，工具経 路情報等の転送回数が減少することから，各 Level2Voxel の干涉 判定に際して必要となるメモリ転送の所要時間が短縮され，干涉 判定の効率が向上寸る. 一方で, GPU 内部のレジスタメモリより も多くの作業用メモリが必要となった場合、GPU 上のテクスチヤ メモリが使用されるため、処理速度の低下が想定される.また, i が小さくなるため LevellVoxel が大きくなり，計算が不要な Level2Voxel の判定を省いて状態を更新する機会が減少寸る.

上記の性質から, 適切な Voxel 数の配分が存在すると考えら 
れ, 今回の評価では $\mathrm{D}=256, \mathrm{D}=512$ の場合共に $\mathrm{n}=32, \mathrm{n}=64$ 付近 で最も所要時間が短くなっている. 今回, 開発の対象とした GPU ハードウェアはアーキテクチャ上の特徴として, 同時実行が可 能なスレッドの最大数が 448 とされており, これに応じて GPU 内部のレジスタ等が分配されて干涉判定を実施している. 試作 システムが使用する作業用メモリ等の関係から, n の増加に伴っ て上記のような効率の向上が見られ, 一定以上の数の Level2Voxel を GPU 内部で並列処理しようとした場合には, 逆に使用可能なレ ジスタメモリ総量の関係から処理速度が低下寸る傾向があること が明らかとなっている.この傾向については GPU の同時実行が可 能なスレッド数・レジスタメモリに依存寸る数值であるため, 今後

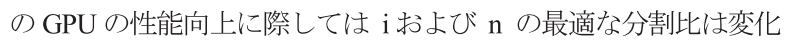
することが想定される.

\section{5. 結}

本研究では, 多軸制御 NC 加工を対象とし, Voxel 表現法を 用いた切削シミュレーションに要する時間を短縮する手法を開 発した。具体的な報告内容は以下の通りである.

(1) Voxel と工具との干渉判定処理を GPU を用いて並列処 理することにより, シミュレーションの所要時間を大幅 に短縮する手法を提案した.

（2）GPU による並列計算の効果を最大限に発揮させるため, Octree 形式の干涉判定を改良した.

（3）Voxel の属性として工具運動のステップ番号を用いるこ とにより, シミュレーションの所要時間を短縮する手法 を開発した。
（4）Voxel のメモリ配列を並列処理に適した形に変更するこ とで, シミュレーションの所要時間を大幅に短縮した.

(5) Level1 と Level2 の Voxel 数の配分の違いによってシミ ユレーション所要時間が変化し, 適切な Voxel 数の配分 が存在することを明らかにした。

\section{参 考 文 献}

1) Takeuchi Y. et al : Development of a Personal CAD/CAM System for Mold Manufacture Based on Solid Modeling Techniques, Ann. CIRP, 38, 1(1989)429.

2) 乾正知：3 軸数値制御工作機械による曲面加工の高速なシミュ レーション，情報処理学会論文誌, 40, 4, (1999), 1808.

3）郝明暉 他：拡張 Z-map モデルによる CAM システムの開発オフセット面生成法の一提案-，精密工学会誌，60，2，(1994）, 275.

4）岸波建史 他：Voxel 表現法の機械加工シミュレータへの忘用, 精密工学会誌, $55,1,(1989), 105$.

5）船津竹史 他：加工除去領域のボクセルモデルを利用した NC 工作機械のアクティブ制御，日本機械学会講演論文集，94, 1 , (2009).

6) Balasuabramaniam M. et al : Generating 5-axis NC Roughing Paths Directly from a Tessellated Representation, Computer-Aided Design, $32,4,(2000), 261$.

7) Hauth S. et al : Extended Linked Voxel Structure for Point-to-mesh Distance Computation and its Application to NC Collision Detection, Computer-Aided Design, 41, 12, (2009), 896.

8）中本圭一 他: ボクセルモデルを用いたヴァーチャルマシニン グシミュレータの開発, 精密工学会誌, 74, 12, (2008), 1308.

9) 乾正知 他: 3 方向デクセルモデルによる同時 5 軸制御加工の 幾何シミュレーション，精密工学会誌, 76, 3, (2010), 361. 